\title{
INDEX TO VOL. 36
}

\author{
(including $C \& R L$ News issues)
}

Prepared by Eldon W. Tamblyn

\section{ABBREVIATIONS}

Standard abbreviations for names of organizations, ALA, ACRL, LC, etc., are alphabetized as if spelled out. Other abbreviations:

$\begin{array}{ll}\text { appt. } & \text {-appointment } \\ \text { coll. (s) } & \text {-college (s) } \\ \text { ed. } & \text {-ditor, edition } \\ \text { inst. } & \text {-institute, institution } \\ \mathrm{n} \text { (before page numbers) } & \text {-CURL News issues } \\ \text { port. } & \text {-portrait } \\ \text { prof. } & \text {-profile } \\ \text { rev. } & \text {-review (er) } \\ \text { univ. } & \text { - university }\end{array}$

\section{A}

Abstracts, $340-44 ; 433-36$ "Academic bibliographic instruction: model statement of objectives," ACRL, Bibliographic Instruction Task Force, n13839 , n169-71

The academic library: essays in honor of Guy $\boldsymbol{R}$. Lyle, Farber and Walling, eds., rev. of, 238

"Access policy guidelines," ACRL, Board of Directors, n322-23

"Acquisition rates in university libraries," Voigt, 263-71

Acquisitions, n8-9; n44; n76-77; n141-46; n184-85; n220 n244; n284; n324; n352-54

Acquisitions (by institution): Archives of American Art, n76; California State Univ., Northridge, n284, n324; Claremont Colls., n244; Coll. of Charleston n44; Columbia Univ. n141-42; Drew Univ. n77; n141-42; Drew Univ. n77; brary, n76, n142, n214 (correction); Georgetown Univ., n354; Iowa State Univ. n44; Lehigh Univ., n185; LC, n220, 284; McGregor Library, n185; Miami Univ. n284; New York Univ., n141; Princeton Univ. n8, n184-85; Smithsonian Inst, n184; Southwestern at Memphis, n352; Temple Univ., n76, n352; Texas A\&M Univ., n44; Univ, of Calgary, n284; Univ, of California: Berkeley, n352; Irvine, n146; Los Angeles, n352;
Univ. of Illinois, n185; Univ. of Missouri, n220, n244; Univ. of North Carolina, n8; Univ. of Notre Dame, n284; Univ. of Oregon, n8-9; Univ, of Puget Sound, n244; Univ. of Southem California, n141-42, n145-46; Univ, of Utah, n352; Univ, of Virginia, n184-85, Un220; Univ. of Wyoming, n76; n220; Univ. of Wyoming,
Wheaton Coll, n8, n354

Acquisitions (by subject, author, or title): American heritage school dictionary material, n354; Armstrong, Walter P., J354; Armstrong, Walter P., Arabic manuscripts, n352; Avery Brundage Collection, n185; Barnes, Harry E., n76; Bell, Alexander G., n220, n284; The book of hawking, hunting and heraldry, n8; Bronte, Lily Hart and The secret, n220; Carrol, Lewis, 141; Catesby, The natural history of Carolina . . . , n44; A commentary on the Pentateuch by Moses ben Nahman, n 145-46; Comell, Joseph, n76; Cutter Laboratories, 1897 1972, n352; Da Vinci, Trattato della pittura, n44; De Wolfe, Billy, n141-42; Dibner Library of the History of Science and Technology, n184; Faulkner, The marionettes, n184-85; The marionettes, n184-85; nii.. n142; Forbes, John, Brig. Gen., n185; Frelinghuysen, Peter H. B., Jr, Hon., n185; Gerard, Ralph W., n146; German politics and culture, n77; Graham, Billy, n8; Han- del, George $F_{1}$, n8; Harper Brothers, n142; Hartford Seminary Foundation, n353; Hemingway, Ernest, n184; Hickey, Margaret, n244; Holinshed, Chronicles, n244; Howells, William D., n284; Keats, John, n184; Korean literature, n354; Lawrence, $T$. E., n244; Ledoux, L'architecture considerée, n220; Milton, Areopagitica, n76; Moore, Brian, n284; Nevins, Allan, n324; Sandburg, Carl, n284; Science fiction. n44; Shirpser, Clara, One woman's role in Democratic Party politics, n352; Social service and civic agency records, n352; Soyer, Moses, n76; Taylor, Paul S., California social scientist, n352; Teeters, Negley $\mathrm{K}$, n76; Tennent, William, Jr., Rev., n184; Vitruvius, $D e$ architectura, n142; Wiswesser line notation, n185; Woltman, Frederick E, n8-9; Young. Whitney M., nl41; Yugoslavian manuscripts in microfilm, n284

Administration of government documents collections, Harleston and Stoffle, rev. of, 158-59

The administration of the college library, 4 th ed., Lyle, rev. of, 327-28

Advances in librarianship, v.5, Voigt, ed., rev. of, 522-23

"Allocating the book budget: an economic model," Gold, 397402

"Allocating the book budget: equity and economic efficiency," Kohut and Walker, 403-10 
"An alternative model of a profession for librarians," Hanks and Schmidt, 175-87

"ANSI Z39 Subcommittee on Serials Holdings Statements formed," n252

Anderson, A. J., Problems in intellectual freedom and censorship, rev. of, 77-78

Anderson, Le Moyne W., letter to the ed. $71-72$; response, 72 ; ed Networks and the university library, rev. of, 418-20

Andrew, Christine, and Balay, "Use of the reference service in a large academic library," 9-26; comment, 322-23; response, 323

Annual review of information science and technology, v.9, 1974 Cuadra, ed., rev. of, 417-18

Application of minicomputers to library and related problems, Lancaster, ed, rev. of, 517-19

"Applying Theory $Y$ to library management," Morton, 302-7; comment, 513

Appointments, n23-26; n61-62; n91-92; n127; n172-73; n201 n229-31; n269-70; n309-10; n338-39; n365

"The approval-built collection in the medium-sized academic library," DeVilbiss, 487-92

Asian and African collections in British libraries: problems and prospects, Benewick, rev. of, $242-43$

"Associate News editor named," nl

The Association of American Library Schools, 1915-1968: an analytical history, Davis, rev. of. 157-58

ACRL. Ad Hoc Committee to Revise the 1959 Standards for college libraries, report, n21-22

ACRL, additional nominees for offices, 1975/76, nl17

ACRL, additional section nominating committees, nl17

ACRL, annual meeting, San Francisco, June 29-July 5 . 1975, programs, n105-17;

ACRL, "Annual report of the president, 1974-75," n213-16

ACRL, Bibliographic Instruction Task Force, "Academic bibliographic instruction: model statement of objectives," n13839. n169-71; "Guidelines for bibliographic instruction in academic libraries," n137-38

ACRL, Board of Directors. "Access policy guidelines," n322-23; annual meeting, San Francisco. June 29-July 5. Francisco, June 29-July 5, "Guidelines for ACRL chapters," n89-90; midwinter meeting. Chicago. Jan. 19-25, 1975. "Highlights," n69-72; policy statement on the M.L.S. degree, n69; comments, n214; n321; n349

ACRL. Committee on Academic Status, "Faculty status for academic librarians: a history and policy statements." publication of, n319; "Model statement of criteria and procedures for appointment. promotion in acapointment. promotion in acalege and university librarians" (C\&RL News 34:192-95), endorsement, $n 78$

ACRL. Committee on Community Use of Academic Libraries,
"Draft: Access policy guidelines," nI67-69

ACRL, "Governance in academic libraries," videotape, n91

ACRL, "Guidelines for branch libraries in colleges and universities," n281-83

ACRL, "Guidelines for two-year college learning resources programs" (C\&RL News 33:30515) committee appointed to write quantitative standards for, $n 283$

ACRL, midwinter meeting, Chicago, Jan. 19-25, 1975, schedule of meetings, n6-7

ACRL, midwinter meeting, Chicago, Jan. 18-24, 1976, tentative schedule of meetings, n350-51

ACRL, New England Chapter, "Report on the Conference on Writing and Publishing for Librarians," nl77-79

ACRL. "New England Chapter of ACRL meets," n1-6; n4l-42

ACRL, Preconference Institute on Collective Bargaining in Higher Education, report on. n241-42, n262

ACRL, Rare Books and Manuscripts Section, placement service, $\mathrm{n} 181$

ACRL, Rare Books and Manuscripts Section, Committee on Manuscripts Collections, "Draft statement on the reproduction of manuscripts and archives for commercial purposes," n96-97; "Universal gift form and instructions," n95-96

ACRL "Standards for college libraries." n277-79, n290-301

ACRL, University Libraries Section, "Networks and the university library," n26; n153; proceedings available, n354

ACRL, University Libraries Section, Urban Universities Library Committee, "Study of urban university libraries consortia," n77

"ACRL' and ALA representatives at academic ceremonies and meetings," n198-99

"ACRL announces faculty status publication." n319

ACRL/AAC/AAUP "Statement on faculty status of college and university librarians" ( $C \& R L$ News 35:26), "Organizations endorsing the statement on faculty status," n57; endorsement. 78

"ACRL cassette on criteria for promotion and tenure," n148

"ACRL first-year interns," n43

"ACRL internship program," n215-16

"ACRL New England Chapter: first election," n198

"ACRL nominating committees, 1976/77 elections," n317-18

"ACRL nominees for offices, $1976 / 77, " n 347-48$

“ACRL officers for 1975/76," n237-39

"ACRL reaffirms statement," n172

"ACRL, reception at San Fran cisco," n181

"ACRL remains largest division," n317

"ACRL to conduct salary survey," n350

ARL, quantitative criteria determining eligibility for membership based on 1973-74 statistics, n140
Aubry, John W., rev, (CATV and its implications for libraries), 418-20; rev. (Networks and the university library), 418-20

Australian libraries, 2d ed., Balnaves and Biskup, rev, of, $524-25$

Axford, H. William, "Annual report of the president 197475," n213-16; "Curtent comments," n2-3; n70-71; port. $n 213$

Ayres, F. H., letter to the ed. 153; response, 153-54

Ayres, F. H., and Hall, J., eds. Information services in univer sity libraries, rev. of, 240

Baaske, Jan; Tolliver, Don L.; and Westerberg, Judy, "Overdue policies: a comparison of alternatives" (CdRL 35:354 59). comments, 71-74; responses, 72-74

Baker, J. Wayne, rev. (Studies in library management, v.2), 335

Balay, Robert, and Andrew, Christine, "Use of the reference service in a large academic library," 9-26; comment, 32223; response, 323

Ball, Joyce, rev. (Administration of government documents collections), 158-59

Balnaves, John, and Biskup, Peer, Australian libraries, $2 \mathrm{~d}$ ed. rev. of, 524-25

The barefoot librarian: library developments in Southeast Asio with special reference to $M a$ laysia, Wijasuriya, Lim and Nadarajah, rev. of, 516-17

Barksdale, Mary Morton, retired, n310

Basler, Roy P., The muse and the librarian, rev. of, 161-62

Baumler, J. L., and Baumler, "A simulation of reserve book activities in a college library using GPSS / $360, " 222-27$

Baumler, J. V., and Baumler, J. L., "A simulation of reserve book activities in a college library using GPSS/360," 22227

Beach, Robert F., retired, n92

Beaupré, Linda, "Report on Peter Drucker's speech at ACRI membership meeting," n263-64 Becerra, Berta, retired, n270

Beckham, Ann L, retired, n310

Beeler, M. G. Fancher; Grim, Jerry; Herling. John P.; James. Stephen; Martin, Miles W.; and Naylor, Alice. Measuring the quality of library service: a handbook, rev, of, 237-38

Bendix, Dorothy, rev. (Fear of the word), 240-41

Benewick, Anne J, Asian and African collections in British libraries: problems and pros pects, rev. of, 242-43

Bennion. Bruce C. letter to the ed., 322-23; response, 323

Benson, Nettie Lee, retired, n310

Bentz. Dale M., rev. (Essays for Ralph Shaw), 515-16

Bergholz, Harry, retired, n270

Bergman, Sherrie S., prof. \& port., n172

Biblarz, Dora; Capron, Margaret. Kennedy, Linda; Ross, Johanna; and Weinerth. David, "Professional associations and un- 
ions: future impact of today's decisions," 121-28

"Bibliographical scholarship in the United States, 1949-1974 a review," Heaney, 493-510

A bibliography of Africana, $\mathrm{Pa}$ nofsky, rev. of, 519-20

Bibliography old \& new, Liebert. rev, of, 234-35

Binder, Michael B., rev. (Reader in library and information services), 523-24

Bird, Nancy K., retired, n26

Biskup, Peter, and Balnaves, Australian libraries, $2 \mathrm{~d}$ ed. rev. of, 524-25

Bitner, Harry, retired, n365

Blomquist, Laura L., and Dougherty, Improving access to library resources. rev, of, 80-81

Bommer, Michael, and Ford, Bernard, "A cost-benefit analysis for determining the value of an electronic security system" (CdrRL 35:270-79), comment, 153; response, 153-54

Bonk, Wallace John, and Magrill and Carter, Building library collections, 4 th ed. rev. of, 82

Book availability and the librar user, Buckland, rev. of, 425-26

Book publishing: what it is, what it does, Dessauer, rev. of, 242

Book reviews, 75-83; 157-62; $229-45 ; 327-35 ; 417-31 ; 515$ 25

Boss, Richard W, rev. (Nonprint media in academic libraries) 430-3I; prof. \& port., n90-91

Bourne, Charles P., rev. (Changing patterns in information retrieval), 333-34

Boyer, Laura M., and Theimer William C., Jr." "The use and training of nonprofessional personnel at reference desks in selected college and university libraries," 193-200

Brazilian serial documents: a selective and annotated guide, Lombardi, rev. of, 235-36

Bregzis, Ritvars, rev. (Computers and early books), 244-45

Bridegam, Willis E., Jr., prof. \& port., n309

Brown. Helen M., rev. (Quiet world), $\mathbf{5 1 7}$

Bruce, Robert K., rev. (Measuring the quality of library service), $237-38$

Bruntjen, Scott, rev. (Classification and indexing in the social sciences, 2d ed.), 520-21

Brynteson, Susan, rev. (Scholar's market), 238-39

Buckland, Michael K., Book a vailability and the library user. rev, of, 425-26

Buckman, Thomas R., and Suzuki and Tiuneishi. eds., Issues in library administration, rev, of, 230-31

Building library collections, 4th ed., Carter, Bonk and Magrill, rev, of, 82

Burckel, Nicholas C. "Establishing a college archives: possibilities and priorities," 384-92

Burns, Mary Anne, and Carter. Jeanette, "Collective bargaining and faculty status for librarians: West Chester State College," 115-20

Burr, Robert L.. rev. (Book availability and the library user), 425-26; letter to the ed. 72 ; response. 72-73; "Library goals and library behavior," 27-32

\section{C}

CATV and its implications for libraries, Thomassen, ed. rev. of, 418-20

Cannan, Judith, rev. (Australian libraries, $2 \mathrm{~d}$ ed. ), 524-25; rev. (An introduction to periodical bibliography), 332-33

Capron, Margaret, and Kennedy, Ross, Weinerth and Biblarz "Professional associations and unions: future impact of today's decisions," 121-28

Carter, Jeanette, and Burns, "Collective bargaining and faculty status for librarians: West Chester State College," 115-20

Carter, Mary Duncan; Bonk, Wallace John; and Magrill, Rose Mary, Building library collections, 4th ed rev of 82

Case studies in library computer systems, Palmer, rev, of, 79-80

Cataloging phonorecordings: problems and possibilities, Daily, rev, of, $429-30$

Changing patterns in information retrieval, Fenichel, ed., rev. of, 333-34

"Characteristics of collections added to American research libraries, $1940-1970$ : a preliminary investigation," Skelley, 52-60; comment, 415; response, 415

Clark, Alice S. and Hirschman, Rita "Using the 'Guidelines': a study of the state-supported two-year college libraries in Ohio," 364-70

Classification and indexing in the social sciences, $2 \mathrm{~d}$ ed., Foskett, rev. of 520-21

Cohen, Nina, rev. (The academic library), 238

Cole, Dorothy Ethlyn, rev. (Book publishing), 242

"Collective bargaining and faculty status for librarians: West Chester State College," Burns and Carter, 115-20

"Collective bargaining and university librarians: Wayne State University," Spang, 106-14

"College and university library survey," $n 349$

Commerton, Anne, "Union or professional organization? A librarian's dilemma," 129-35

Comparative historical analysis of three associations of professional schools, Davis, rev. of, 157-58

Computers and early books: report of the LOC Project... rev. of, $244-45$

Conference on library orientation, 5th, "Faculty views on library instruction," videocassettes available, n319

"Conference/Workshop on Bibliographic Instruction for Library Users," Roberts, n1-6; n41-42

“CONSER pact signed" n81

Copeland, Isaac, retired, n270

"A cost-benefit analysis for determining the value of an electronic security system," Bommer and Ford ( $C \& R L$ 35:270-79), comment, 153; response, 15354

CLR, Fellowship Committee, seyenth class of CLR fellows, n182-83

"CLR annual report available," n 146

"CLR Board elected," n97

Cuadra, Carlos A., ed., Annual review of information science and technology, v.9, 1974, rev. of, 417-18

"Current comments," Axford, n2$3 ; n 70-71$

D

Daily, Jay E. Cataloging phonorecordings: problems and possibilities, rev. of, 429-30

Daiute, Robert J., and Gorman, Kenneth A., Library operations research, rev. of, 329-30

Daniel, Evelyn H, and Reynolds, eds., Reader in library and information services, rev. of, 523-24

Davies, D. W., rev. (Publishing and bookselling, 5th ed.), 78 -

Davis, Donald Gordon, Jr., The Association of American Library Schools, 1915-1968: an analytical history, rev, of 157 58; Comparative historical analysis of three associations of professional schools, rev. of 157-58

Davis, James $R$. "The new students: what they read " 216-21

Deale, H. Vail, "MALC's second decade: commitment to communication," 143-51

Deaths, n26; n62; n92; n129; n201; n231; n271; n310; n339; n365

Debenham, W. Stuart, rev. (Problems in developing academic library collections) 82-83

Dessauer, John P., Book publishing: what it is, what it does, rev. of, 242

Developing libraries in Brazil McCarthy, rev, of, 422

DeVilbiss, Mary Lee, "The approval-built collection in the medium-sized academic library," 487-92

Dollard, Peter, rev. (Weeding library collections), 424-25

Doolittle, Gladys, deceased, n271

Dougherty, Fichard M. and Blomquist, Laura L., Improving access to library resources, rev. of, $80-81$

Dowling, Anne, appt. \& port., n1

Downing, Elaine L.. appt., n5

Downs, Robert Bingham, ed. Guide to Illinois library resources, rev, of, 76-77

"Draft: Access policy guidelines," ACRL, Committee on Commu nity Use of Academic $\mathrm{Li}$ braries, n167-69

"Draft statement on the reproduc tion of manuscripts and archives for commercial purposes," ACRL, Rare Books and Manuscripts Section. Committee on Manuscripts Collections, n96-97

Drazniowsky, Roman, comp., Map librarianship: readings, rev. of, 422-23

"Drexel Library School is OCLC affiliate," n239

Drucker. Peter. port., n105; speech at ACRL membership meeting, report on, n263-64

Duignan, Peter, rev, (A bibliography of Africana), 519-20

Dukes. Eugene D., letter to the ed. n349

Dunkin, Paul Shaner, deceased, n339

Dunlap, Connie R.. prof. \& port., n229; port., n237

Dyson, Allan J., rev, (Educating the library user), 233-34 


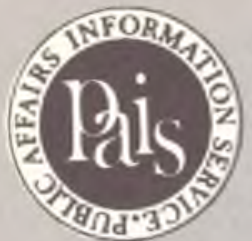

\section{OUTSTANDING COVERAGE OF 20TH CENTURY \\ ECONOMICS, POLITICAL SCIENCE, AND INTERNATIONAL RELATIONS}

Unique among the major indexing services in the Social Sciences, PAIS offers selective coverage of the full spectrum of printed materials in its major fields of interest.

The fact that no type or format of publication is specifically excluded, results in the inclusion of English Language books, pamphlets, government publications (national, state, local and foreign), studies and reports by public and private institutions (including corporations), processed material, and, of course, a truly large selection of periodicals. Currently, PAIS in dexes more than 1000 periodicals, as compared to 160 for Readers Guide, 262 for The Social Science Index, 260 for the Humanities Index, 156 for Business Periodicals Index, and 375 for the British Humanities Index Many of the various types of publications indexed by PAIS include materials published in foreign countries which have been translated or otherwise made available in the English Language.

As for scope, the broad PAIS interpretation of "public affairs" over the years has proven increasingly important as more and more public problems cut across

traditional disciplinary boundary lines. Such subjects as "energy" for instance, now fall under a variety of PAIS categories, including business and economics, politics and public administration, sociology, and even international relations. Subject searchers in the "energy" field would find this combination of full coverage in PAIS, but not in indexing services of more limited scope.

Selectivity criteria emphasize factual and statistical information, and still follow the philosophy of Charles Williamson, one of the PAIS founders who wrote in 1919 that "The PAIS is not, and should not attempt to be, a systematic index of a definite list of periodicals or other publications. It should aim to present only the best and most useful material, carefully selected from a wide range of sources, with a view to furnishing its subscribers, consisting mainly of general and special libraries, a guide in building up their collections and at the same time an index to their collections."

NO PREVIOUS MULTI-ANNUAL SUBJECT CUMULATIONS Until now, PAIS has offered no cumulations covering periods greater than one year. This has meant that in order to conduct exhaustive research on a topic, or even to locate a work whose date of publication was unknown, the reader has had to search year-to-year through large numbers of annual Bulletins.

COMPLETE RETROSPECTIVE SEARCHING IN ONE ALPHABET INSTEAD OF SIXTY This 60 year cumulative index, with its more than 1.2 million entries interfiled by subject into one alphabetical sequence, is contained in fifteen folio-size volumes, casebound to stand up under the heavy reference use they will receive.

The more widely used a particular reference tool, the greater the aggregate savings if and when non-productive search time can be cut down or eliminated. Therefore, considering the popularity and accepted reference use of the retrospective run of the PAIS Bulletin the savings resulting from the availability of its Cumulative Subject Index should be substantial.

Also, of course, both the dollar savings and the gains in research efficiency are benefits which will repeat themselves year after year-and will continue long after the one-time cost of this Subject Index has been forgotten. Actually, at the pre-publication price of $\$ 1,075.00$, the approximately 1.2 million interfiled subject entries are being offered at less than 90 cents per thousand.

THE COST EFFECTIVENESS OF CUMULATIVE INDEXES LeRoy Schwarzkopf, the well known documents librarian, explained the cost effectiveness of cumulations of long runs of periodical indexes in his review of the Carrollton's other 15 volume single-alphabet index, the 72 year Index to the Monthly Catalog of U.S. Government Publications, 1900-1971. In his two-page review, which appeared in the 1975 edition of American Reference Book Annual, he concluded by stating that although the price of the set may seem expensive, " . . . when judged by its value in practical use, in time saved for librarians and other users of federal documents, and in the more exhaustive searches which it allows and encourages, the set is quite inexpensive and is considered to be an outstanding bargain." 
The most comprehensive English Language Index to the social sciences will now have a single source of subject access for its entire sixty year run...

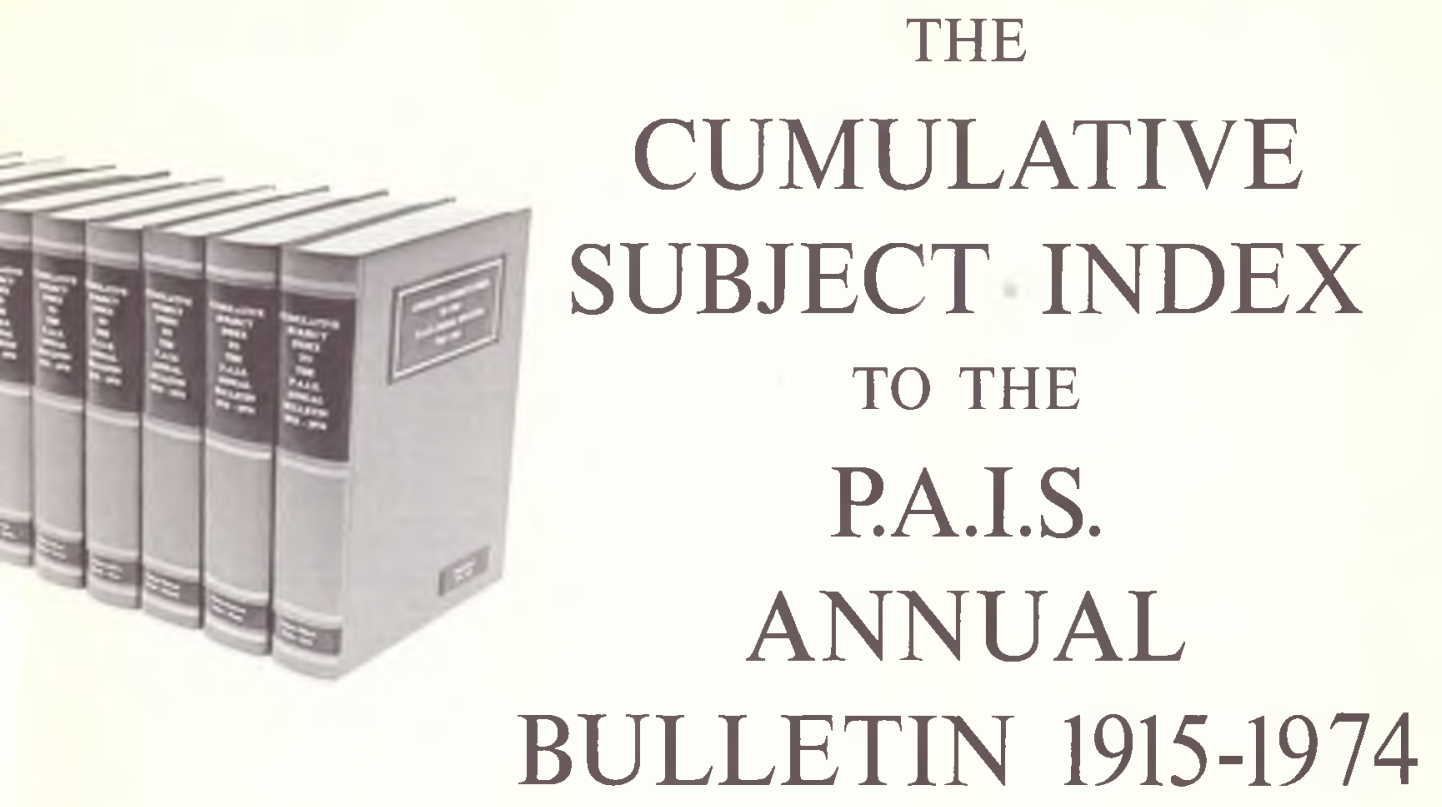

By special arrangement with the Public Affairs Information Service, Carrollton Press is adding the vital factor of cumulative indexing to the recognized reference value and unparalleled coverage of the PAIS Bulletin.

The combination should result in one of the largest and most effective subject reference systems ever produced in the social sciences.

For libraries not already holding complete runs of the PAIS Annual Bulletin we also offer the quality facsimile volumes produced by the Kraus Reprint Company. These cover the years 1915-1965 and are available for immediate delivery either as a set or as single volumes.

\section{Use this coupon to record your index order at pre-publication prices.}

\section{Carroliton Press, Inc., 1911 Ft. Myer Drive, Arlington, Virginia 22209}

Please record our order for

$\square$ The Cumulative Subject index to the PAIS Annual Bunletins 1915-1974 in 15 volumes, casebound

$\$ 1,075.00$

- Facsimile reprint volumes of the PAIS Annual Bulletins, vols, 1-51 (1915-1965) produced by the Kraus Reprint Company, 52 volumes casebound (immediate delivery)

Individual volumes $1-48$ @ $\$ 36.00$ each; $49-51 @ \$ 53.00$ each.

$\$ 1,911.00$

The Combined Reference Edition: The complete Kraus Reprint edition of the PAIS Bulletin plus the Cumulative index to the PAIS Annual Bulletins 1915-1974 (note savings of $\$ 126.00$ on the combined purchase)

Please send us your free brochure which describes the project in detail. 
Easterly, Ambrose, rev. (The administration of the college $l i$ brary, 4 th ed.) , 327-28

Eastern Michigan University, Center of Educational Resources, "Faculty views on library instruction," videocassettes available, n319; "Slidetape library orientation program." n39

Educating the library user, Lubans, ed, rev of, 233-34

"The effect of reduced loan periods on high use items," Yagello and Guthrie, 411-14

Essays for Ralph Shaw, Stevens, ed. rev, of, 515-16

"Establishing a college archives: possibilities and priorities," Burckel, 384-92

\section{F}

"Factors in the organization of SOLINET," Gribbin, n37-39

"Faculty status for academic librarians: a history and policy statements," ACRL, Committee on Academic Status, publication of, n319

"Faculty views on library instruction," videocassettes available, n319

Farber, Evan Ira, and Walling, Ruth, eds., The academic library: essays in honor of Guy R. Lyle, rev. of, 238

Fear of the word: censorship and sex, Oboler, rev. of, 240-41

Fellowships. n44; n185-86; n354

Fenichel, Carol, ed.. Changing patterns in information retrieval, rev. of, 333-34

Field, F Bernice, deceased, n26

Folger Library correction, n214 (see n142)

Folmer. Fred, retired, n270

Ford, Bernard, and Bommer, "A cost-henefit analysis for determining the value of an electronic security system" ( $C$ d $R L$ 35:270-79). comment, 153; response, $153-54$

Foreman, Lewis, Systematic discography, rev, of, 241-42

"Former librarian nominated as Gulf director: oil on troubled waters?" n192

Foskett, D. J., Classification and indexing in the social sciences, 2d ed,, rev, of, 520-21

Fox, Peter, Reader instruction methods in academic libraries, 1973 rev of 328-29

"Friends of the library," Gwyn, McArthur and Furlow, 272-82

"From economic to political analysis of library decision making." Raffel (CoRL 35: 412-23), comment, 154 ; response, i54

"From the chair of the presidency," Schure, 188-92

Furlow, Karen. and Gwyn and McArthur, "Friends of the Library," 272-82

\section{G}

Garrabrant, William A., letter to the ed.. 513

Gifts, n186

Giles, Louise, port.. n237

Givens. Johnnie, "Report to the ACRL membership from the Ad Hoc Committee to Revise the 1959 Standards for college libraries," n21-22

Gold, Steven D., "Allocating the book budget: an economic model," 397-402

Gorman, Kenneth A., and Daiute, Library operations research, rev, of, 329-30

Grants, n77-78; n109; n146-47 n186; n220-26; n244-47 n284-85; n324-29; n354-57

Grants (by grantee): American Council of Leamed Societies, n324; ALA, n222; ARL n245; Boston Theological Inst. n186; Case Western Reserve Univ, n285. n356; Eastern Michigan Univ., n77, $\mathrm{n} 186$ lowa State Univ., n78; LC. National Serials Data Program n284-85; Mills Coll., n77; Portland State Univ., n324; Society of American Archivists. n357; Stanford Univ., n109, 222; Temple Univ., Urban Archives Center, n226; Univ. of Chicago, $\mathbf{n} 222$; Univ. of Denver, n355; Univ, of Kentucky, $\mathbf{n 7 7}$; Univ, of Michigan. n220-22; Univ. of Pittsburgh n147; Univ, of South Carolina. n354; Univ, of Southern California, n356

Grants (by grantor): American Antiquarian Society, n329 Cleveland Foundation, n285, n356; CLR, n77, n186, n222 26. n245-47, n284-85, n324. G. Gund Foundation, n356 Immigration History Research Center, n244-45; J. Irvine Foundation, n109; L. B. Johnson Foundation, n324-25; L. H. Bostick Trust, n354; M. Falk Medical Fund, nl47 NEA, n78; NEH, n77. n284 85, n357; NSF, n220-22; OAS n35: USOE, n356; Univ. of Hawaii, n146; W. Penn Foundation, $n 226$

Greene, Robert J., "LENDS: an approach to the centralization/decentralization dilemma," 201-7

Gribbin, John H. "Factors in the organization of SOLINET," n37-39

Grieder, Ted, rev. (Shaping a $l$ brary), 232-33

Grim, Jerry, and Herling, James, Martin, Naylor and Beeler, Measuring the quality of library service: a handbook, rev. of, 237-38

Grove Pearce $\mathbf{S}$ ed Nonprint media in academic libraries, rev. of, 430-31; prof. \& port. n338

Grunder, Henry, letter to the ed. 415; response, 415

Guide to Illinois library resources, Downs, ed., rev, of, 76-77

A guide to research in American library history, 2d ed., Harris, rev. of, $330-31$

A guide to the Archives of Labor History and Urban Affairs, Wayne State University, Pflug, comp. and ed, rev, of, 334-35

"Guidelines for ACRL chapters," ACRL. Board of Directors, n89-90

"Guidelines for bibliographic instruction in academic libraries," ACRL, Bibliographic Instruction Task Force, nI37-38

"Guidelines for branch libraries in colleges and universities," ACRL, n281-83

"Guidelines for two-year college learning resources programs," ACRL (CoRL News 33:305. 15), committee appointed to write quantitative standards for, $n 283$

Guido, John F, rev, (Bibliography old \& new) 234-35; rev (Readings in descriptive bibliography), 234-35

Guthrie, Gerry, and Yagello, "The effect of reduced loan periods on high use items," 411 14

Guyton, Theodore Lewis, Unionization: the viewpoint of $l i$ brarians, rev, of, 428-29

Gwyn, Ann: McArthur Anne and Furlow, Karen, "Friends of the library," 272-82

\section{$\mathrm{H}$}

Hadlock, Robert L., letter to the ed., 154; response, 154

Haider, Syed Jalaluddin, "University libraries in Pakistan," 379 83

Hall, J., and Ayres, eds,, Information services in university libraries, rev. of, 240

Hanks, Gardner, and Schmidt C. James, "An alternative model of a profession for libraris, 175-87

Harding, Thomas $S_{1}$ retired. n270

Harleston, Rebeksh M., and Stoffle, Carla J., Administra tion of government documents collections, rev, of 158-59

Harmon, Gary L., and Harmon, Susanna M.. Scholar's market an international directory of periodicals publishing literary scholarship, rev. of, 238-39

Harmon, Susanna M. and Harmon. Scholar's market: an international directory of periodicals publishing literary scholarship, rev. of, 238-39

Harrar, H. Joanne, prof. \& port. n269

Harreld, Jennie M., "Report on the Conference on Writing and Publishing for Librarians,' n 177-79

Harris, Michael H. A guide to research in American library history, $2 \mathrm{~d}$ ed., rev. of, 330 31

Harter, Stephen P., letter to the ed., 73-74; response, 74

Harvey, John $\mathrm{F}$. rev. (Issues in library administration) 230-31

Heaney, Howell J., "Bibliographical scholarship in the United States, 1949-1974: a review," 493-510

Helfer, Joseph, appt,, n170

Helzer, Charles, rev. (Irving to Irving), 236-37

Herling, John P., and James, Martin, Naylor, Beeler and Grim, Measuring the quality of library service: a handbook, rev, of, 237-38

Higgins, Gertrude, retired, n62

Hirschman, Rita, and Clark, "Using the 'Guidelines': a study of the state-supported two-year college libraries in Ohio," 364-70

A history of book publishing in the United States, V.2, Tebbel. rev. of, 423-24

Hoadley, Irene Braden, rev. (Information services in university libraries). 240

Hock, Randolph E., "Providing access to externally available 
bibliographic data bases in an academic library," 208-15

Hoffman, Herbert $H$, letter to the ed., 73 ; response, 73

Holroyd, Gileon, ed., Studies in library management, v. 2 , rev. of, 335

Horn, Roger, "The idea of academic library management," 464-72

Horny, Karen, rev. (Building $l$ brary collections, 4th ed.), 82

Hostetter, John D., deceased, n310

Hoyle. Norman, rev. (The muse and the librarian), 161-62

Huston, Evelyn, retired, n365

\section{I}

"The idea of academic library management," Horn, 464-72

Improving access to library re sources, Dougherty and Blomquist, rev. of, $80-81$

Indiana authors and their books, 1917-1966, Thompson, rev, of 79

Information services in university libraries, Ayres and Hall, eds. rev. of, 240

"Inside Washington," Wright, n4, n40-41; n73-75; n108; n141 n180-81; n217-18; n240 n260-61; n280; n320-21

Instructions for authors, $32 ; 105$. $200 ; 324$

Interlibrary loan policies directory, Thomson, rev. of, 429

An introduction to periodical bibliography, Vesenyi, rev. of, 332-33

Introduction to United States public documents, Morehead rev. of, 331-32; response. 513

Irvine, Betty Jo, Slide libraries: a guide for academic institutions and museums, rev, of, 76

Irving to Irving: author-publisher relations, 1800-1974, Madison, rev. of, $236-37$

Isstues in library administration, Tsuneishi, Buckman and Suzuki, eds., rev. of, 230-31

\section{$\mathrm{J}$}

Jackson, Sidney L., Libraries and librarianship in the West: brief history, rev. of, 75-76 response, 323-24; rejoinder, 324

Jackson, William Vernon, rev. (Brazilian serial documents), 235-36

James, Stephen, and Martin, Naylor, Beeler, Grim and Herling, Measuring the quality of library service: a handbook, rev of, $237-38$

Jármy, Imre $T$. Newspapers in microform, correction, 69 (see C URL 35:250)

"Job satisfaction of librarians: a comparison between men and women," Wahba, 45-51

Johnson, Edwina D., retired, n310

Johnson. Peter T., rev. (Developing libraries in Brazil), 422

Johnson, Richard D.. "A new year," editorial, 7; "Topic A," editorial, 95

Jones, Harold D., "Postwar university library buildings in West Germanv," 283-94

Jones, John Bush. ed. Readings in descriptive bibliography, rev. of, $234-35$

Josey, E. J., ed., New dimensions for academic library service, rev. of, 426-27

\section{$\mathrm{K}$}

Kansas Library Association, Col lege and University Libraries Section, endorsement, n78

Kaplan, Louis, "The literature of participation: from optimism to realism," 473-79

Karlson, Marjorie, rev. (Interlibrary loan policies directory) 429

Kaser, David, rev, (A history of book publishing in the United States, v.2), 423-24; rev. (Indiana authors and their books, 1917-1966), 79; presidentelect, Beta Phi Mu International, n42; request for library building picture postcards, n39

$\mathrm{Kay}, \mathrm{Olga}$, retired, $\mathrm{n} 92$

Kemper, Robert E., rev. (Library operations research), 329-30

Kennedy. James R. Jr., Library research guide to religion and theology, rev. of, 162

Kennedy, Linda, and Ross, Weinerth, Biblarz and Capron "Professional associations and unions: future impact of today's decisions," 121-28

Kenney, Louis A., letter to the ed. n214; comment, n349

Kiewitt, Eva L., "A user study of a computer retrieval system," 458-63

Kilgour. Frederick G., rev. (Case studies in library computer systems), 79-80

Knightly, John J., "Library collections and academic curricula: quantitative relationships,' 295-301

Koehler, Valentine J., Rev., O.S.B. deceased, $n 92$

Kohut, Joseph J., and Walker, John F., "Allocating the book budget; equity and economic efficiency," 403-10

Kuhner, David, rev, (Using the chemical literature), 243-44

\section{I.}

"LENDS: an approach to the centralization/decentralization dilemma," Greene, 201-7

Ladd, Dwight R., "Myths and realities of university governance," 97-105

Laird, W. David, rev. (Libraries and librarianship in the West). $75-76$; response, $323-24$; rejoinder, 324

Lancaster, F. Wilfrid, ed, Application of minicomputers to library and related problems, rev. of, 517-19

Lang, Jovian, Rev, rev, (New dimensions for academic $l i$ brary service), 426-27

Lawson, Vivien M., deceased, n201

Lee, Robert, and Wilkinson and Plate, "A matrix approach to position classification," 351-63 position classification, $351-63$
Lemen, Wilhelmina, retired, n310

Lentz, Robert T., retired, n270

Letters, 71-74; 153-54; 322-24; 415; 513; n214; n321; n349

Lewis, John D., Jr., deceased, n310

"Librarian named faculty senate president," n253

Libraries and librarianship in the West: a brief history. Jackson, rev. of, 75-76: response, 32324; rejoinder, 324
"Libraries, economics and information: recent trends in information science literature," Pratt, 33-38

"Library collections and academic curricula: quantitative relationships," Knightly, 295-301

"Library goals and library behavior," Burr, 27-32

Library manpower: a study of demand and supply, rev. of, $427-$ 28

Library operations research, Daiute and Gorman, rev. of, 329-30

Library research guide to religion and theology, Kennedy, rev. of, 162

"Library services to educationally disadvantaged students," Shaughnessy, 443-48

Liebert, Herman W., Bibliography old \& new, rev. of, 234 35

Lim, Huck Tee, and Nadarajah and Wijasuriya, The barefoot librarian: library developments in Southeast Asia with special reference to Malaysia, rev. of, 516-17

Line, Maurice B., and Sandison, Alexander, "Practical interpretation of citation and library use studies," 393-96

"The literature of participation from optimism to realism," Kaplan, 473-79

Local library cooperation, Wilson and Marsterson, rev. of, 420 21

Lombardi, Mary, Brazilian serial documents: a selective and annotated guide, rev of 235-36

London, Lawrence, retired, n270

Lowell, Howard P., letter to the ed., 322

Lubans, John, Jr., ed., Educating the library user, rev, of, 23334 Lucker, Jay K., prof. \& port.,
n125-27

Luckett, George R., retired, n92

Lundy, Frank A., deceased, n231

Lyle, Guy R., The administration of the college library, 4 th ed. rev. of, 327-28

\section{M}

"MALC's second decade: commitment to communication," Deale, 143-51

McAlister, Dorothy, retired, n231

McArthur, Anne, and Gwyn and Furlow, "Friends of the li brary,"' 272-82

Mac Carter. Beatrice, retired, n62

McCarthy, Cavan, Developing libraries in Brazil, rev, of, 422

McCoy, Ralph E., retired, n365

McKenna, John R., deceased n365

Madison, Charles A., Irving to Irving: author-publisher rela tions, 1800-1974, rev. of, 236 37

Magrill. Rose Mary, and Carter and Bonk, Building library collections, 4 th ed., rev. of, 82

Map librarianship: readings, Drazniowsky, comp., rev, of, 422-23

Marchant, Maurice P., "University libraries as economic systems," 449-57

Marcum, Deanna Hudson, rev. (Annual review of information science and technology, v. 9 , 1974), 417-18 
Marsterson. W. A. J., and Wilson, Local library cooperation, rev. of, $420-21$

Martin, Miles W., and Naylor Beeler, Grim, Herling and James, Measuring the quality of library service: a handbook, rev. of, 237-38

"A matrix approach to position classification." Wilkinson, Plate and Lee, 351-63

Maurice Falcolm Tauber a biobibliography, 1934-1973, Szigethy, rev. of, 231-32

Maxwell, Margaret, Shaping a li brary: William L. Clements as collector, rev, of, 232-33

Measuring the quality of library service: $a$ handbook, Beeler, Grim, Herling, James, Martin and Naylor, rev, of, 237-38

Meetings, $n 9-11 ; n 44-49 ; n 78-$ 82; n109-12; n147-51; n186 $89 ; \mathrm{n} 226 ;$ n2 $47-49 ;$ n285-86; n329-31; n357-61

Meyhoefer, Ida, retired, n173

Miller, J. Gormly, prof. \& port., n 3

"Model statement of criteria and procedures for appointment, promotion in academic rank. and tenure for college and university librarians," ACRL. versity librarians, ACRL, Committee on Academic Status
(C\&RL News 34:192-95), endorsement, $n 78$

"Models and methods: the tools of library networking," Parker. $480-86$

Mohrhardt, Foster, retired, n231

Monahan, M. Denise, Sister, I.H.M, deceased, n26

Morehead. Joe, Introduction to United States public documents, rev. of, $331-32$; response, 513

Morton, Donald J., 'Applying Theory $\mathbf{Y}$ to library management, "302-7; comment, 513

Mumby, Frank Arthur, and Norrie. Ian, Publishing and bookselling, 5th ed., rev, of, 78-79

Murdock, Aileen A., retired, n173

The muse and the librarian, Basler, rev. of, 161-62

"Myths and realities of university governance," Ladd, 97-105

\section{$\mathrm{N}$}

Nadarajah, Radha, and Wijasuriya and $\mathrm{Lim}$, The barefoot librarian: library developments in Southeast Asia with special 516-17

"Name C\&RL Assistant Editor," n5

'National catalog of Asian materials needed," conference report, Sharma, n345-46

Naylor, Alice, and Beeler, Grim, Herling, James and Martin, Measuring the quality of library service: a handbook, rev. of, $237-38$

"Networks and the university library," ACRL, University Libraries Section, proceedings available, n354; Anderson, ed. rev, of, $418-20$

New dimensions for academic li brary service, Josey, ed., rev. of, 426-27

"New England Chapter of ACRL meets," Roherts, n1-6; n41-42

The new Sabin, Thompson, comp., rev. of, $81-82$
"New science editor for Choice," $\mathrm{nI70}$

"The new students: what they read," Davis, 216-21

"A new year," Johnson, editorial,

New York Conference for Asian Studies, report, n345-46

Newman, Richard, letter to the ed., 71

News from the field $n 8-20 ; n 44$ 54; n76-96; nI09-13; nI4163; n184-97; n220-26; n24460 ; n284-89; n324-37; n35264

Newspapers in microform, correction, 69 (see C\&RL 35:250)

Nonprint media in academic libraries, Grove, ed., rev. of, 430-31

Norrie, Ian, and Mumby, Publishing and bookselling, 5th ed., rev, of, $78-79$

\section{O}

Oaksford, Margaret J., rev. (Guide to Illinois library resources), 76-77

Oboler, Eli M., Fear of the word: censorship and sex, rev. of. $240-41$; rev. (Problems in intellectual freedom and censorship), 77-78

"Oboler plans a (nother) new library for Idaho State," n183

O'Keeffe, Richard L., rev. ( $A d$ vances in librarianship, y.5) 521-23

Other publications of interest to academic librarians, 83-84; $162-63 ; 245-49 ; 336-39 ; 431$ $33 ; 525-26$

"Overdue policies: a comparison of altematives," Baaske, Tol liver and Westerberg ( $C \& R L$ 35:354-59), comments, 71-74 responses, $72-74$

\section{$\mathbf{P}$}

Palmer, Foster M., retired, n92

Palmer, Richard Phillips, Case studies in library computer systems, rev, of, 79-80

Panofsky, Hans E., A bibliography of Africana, rev. of, 519 20

Parish, David W. State government reference publications: an annotated bibliography, rev. of, 159-60

Parker, Thomas F., "Models and methods: the tools of library networking " 480-86

People, n23-26; n61-62; n90-92; n125-29; n172-73; n201 n229-31; n269-71; n309-10 n338-39; n365

"Periodicals and the liberal arts college library," Stewart, 37178

Peterson, Kenneth G., rev. ( $A$ guide to research in American library history, 2d ed.), 33031

Pflug, Warner W., comp. and ed., $A$ guide to the Archives of 'Labor History and Urban Affairs, Wayne State University, rev. of, 334-35

Plate, Kenneth, and Lee and Wil kinson, "A matrix approach to position classification," 351-63

Policy statement on the MIS. degree, ACRL, Board of Directors, n69; comments, n214; n321; n349

"Postwar university library build- ings in West Germany," Jones, 283-94

Powell, Benjamin E., retired, n.310

Powell, Janice J., rev. (Library manpower), 427-28

"Practical interpretation of citation and library use studies," Line and Sandison, 393-96

Pratt, Allan D.. "Libraries, eco nomics and information: recent trends in information science literature," 33-38

"Preservation efforts in larger U.S, academic libraries," Walk er. 39-44; comment, 322

Problems in developing academic library collections, Schad and Tanis, rev. of, 82-83

Problems in intellectual freedom and censorship, Anderson, rev of, $77-78$

"Professional associations and unions: future impact of today's decisions," Biblarz, Capron, Kennedy, Ross and Weinerth, 121-28

Profiles, n23; n61; n90-91; n12527; n172; n229; n269; n309; 338

"Providing access to externally available bibliographic data bases in an academic library," Hock, 208-15

Pryor, Lewis A., retired, $n 129$

Publications, n16-20; n51-54; n85-88; n112-13; nI61-63 n193-97; n252-60; n287-89; n335-37; n362-64

Publishing and bookselling, 5th ed., Mumby and Norrie, rev. of, $78-79$

Pullen, William R., deceased, n62

\section{Q}

Ouiet world: a librarian's crusade for destiny, Shores, rev, of, 517

\section{R}

Rader, Hannelore B., rev. (Reader instruction methods in academic libraries, 1973), 328-29

Raffel, Jeffrey A., "From economic to political analysis of library decision making" (C\&RL 35:412-23), comment, 154 ; response, 154

Randall, David, deceased, n231

Reader in documents on international organizations, Stevens and Stevens, eds, rev, of 160

Reader in library and information services, Reynolds and Daniel, eds., rev. of, 523-24

Reader instruction methods in academic libraries, 1973, Fox, rev. of, 328-29

Readings in descriptive bibliography, Jones, ed., rev. of, 23435

Recent publications, 75-84; 157 63 ; $229-49 ; 327-44 ; 417-36$; 515-26

Reeves, Pamela W., prof, \& port., n269

Retirements, n26; n62; n92; n129; n173; n231; n270-71; n310; n339; n365

Reynolds, Carroll F., deceased, n339

Reynolds, Michael M., and Daniel, Evelyn H., eds., Reader in library and information services, rev. of, 523-24

Richmond, Phyllis A, rev. (Maurice Falcolm Tauber), 231-32 
Rift, Leo R., letter to the ed., n321

Roberts, Anne, "Conference/ Workshop on Bibliographic Instruction for Library Users," n41-42; "New England Chapter of ACRL meets," nl-6

Rosenberg, Kenyon C., rev. (Systematic discography), 241-42

Ross, Johanna, and Weinerth, Biblarz, Capron and Kennedy, "Professional associations and unions: future impact of today's decisions," 121-28

Rothstein, Samuel, rev. (The Association of American Library Schools, 1915-1968), 157-58; rev. (Comparative historical analysis of three associations of professional schools) 157-58

Rowley, Dorothy S., retired, n270

Rudolph, G. A., rev. (Simulation teaching of library administration), 421

Rumble, Lucy K., retired, n270

Ryan, Mary J., rev. (Reader in documents on international organizations), 160

\section{$\mathrm{S}$}

Sandison, Alexander, and Line, "Practical interpretation of citation and library use studies," 393-96

Schad, Jasper G., and Tanis, Norman E., Problems in developing academic library collections, rev. of, 82-83

Schliecker, Charles, retired, n270

Schmidt, C. James, and Hanks, "An alternative model of a profession for librarians," 175-87

Scholar's market: an international directory of periodicals publishing literary scholarship, Harmon and Harmon, rev, of 238-39

Scholberg, Henry, rev. (The barefoot librarian), 516-17

Schorr, Alan Edward, rev. (Introduction to United States public documents), 331-32; comment, 513

Schubach, Bernice W., retired, n129

Schure, Alexander, "From the chair of the presidency," 188 92

"Selected reference books of 1973-74," Sheehy, 6I-69; cor rection, 69 ( see C\&RL 35: 250)

"Selected reference books of 1974-75," Sheehy, 308-20

Sellers, David Youngs, deceased, n62

Shaping a library: William $L$. Clements as collector, Max well, rev. of, 232-33

Sharma, Ravindra N., "National catalog of Asian materials needed." conference report n345-46

Shaughnessy, Thomas W., "Library services to educationally disadvantaged students," 44348

Sheehy, Eugene P., "Selected reference books of 1973-74," 6169 ; correction. 69 (see $C$ \& $R I$ 35:250); "Selected reference books of 1974-75," 308-20

Shepherd, Freemont (Giles), retired, n92

Shillaber. Caroline, retired, n231

Shores, Louis, Quiet world: a librarian's crusade for destiny, rev, of, 517
Shuford, Mary Opal, retired, n310

Shumaker, Earl, rev. (State government reference publications), $159-60$

Simonds, Michael J., "Work attitudes and union membership," $136-42$

Simnns, Wendell W., rev. (Slide libraries), $\mathbf{7 6}$

"A simulation of reserve book activities in a college library using GPSS/360," Baumler and Baumler, 222-27

Simulation teaching of library administration, Zachert, rev. of 421

Skelley, Grant T., "Characteristics of collections added to American research libraries, 1940-1970: a preliminary investigation," 52-60; comment 415 ; response, 415

Slanker, Barbara, rev. (Improving access to library resources), 80 81

Slide libraries: a guide for academic institutions and museums, Irvine, rev, of, 76

"Slide-tape library orientation program," Eastern Michigan University, Center of Educational Resources, n39

Slote, Stanley J., Weeding library collections, rev. of, 424-25

Smith, Frances Shaver, deceased, n62

Smith, Jessie Carney, "Special collections of black literature in the traditionally black college" (C\&RL 35:322-35), comment, 71

Snapp, Elizabeth, rev.: (Local library cooperation), 420-2

Spang, Lothar, "Collective bargaining and university librarians: Wayne State University, 106-14

"Special collections of black literature in the traditionally black college," Smith (CURL $35: 322-35$ ), comment, 71

"Standards for college libraries," ACRL, n277-79, n290-301

State government reference publications: an annotated bibliography, Parish, rev, of, $159-60$

"Statement on faculty status of college and university librarians," ACRL/AAC/AAUP (Cd-RL News 35:26), "Organizations endorsing the state-
ment on faculty status," n57; endorsement, $n 78$

Stauffer, Dorothy H., retired, n 129

Stevens, Helen C., and Stevens, eds., Reader in documents on international organizations, rev. of, 160

Stevens, Norman D., ed., Essays for Ralph Shaw, rev. of, 515 16

Stevens, Robert D., and Stevens, Helen C., eds. Reader in documents on international organizations, rev. of, 160

Stevenson, Gordon, rev. (Cataloging phonorecordings), 429-30

Stewart, Blair, "Periodicals and the liberal arts college library," 371-78

Stoffle. Carla I. and Harleston Administration of government documents collections, rev, of, $158-59$

Strassberg, Richard, rev. (A guide to the Archives of Labor His tory and Urban Affairs, Wayne
State University), 334-35

Studies in library management, v. 2, Holroyd ed, rev of, 335

Stueart, Robert D., prof. \& port. n61.

Suzuki, Yukihisa, and Tsuneishi and Buckman, eds., Issues in library administration, rev. of 230-31

Sweet, Doris Ann, rev. (The new Sabin), 81-82

Systematic discography, Foreman, rev. of, 241-42

Szigethy, Marion C., Maurice Falcolm Tauber, a biobibliography, 1934-1973, rev. of, 231 32

\section{$\mathrm{T}$}

Tanis, Norman E., and Schad, Problems in developing academic library collections, rev. of, 82-83

Tarver, Elizabeth, retired, n92

Tebbel, John, A history of book publishing in the United States, v.2, rev. of, 423-24

Theimer, William $C$, Jr, and Boyer, "The use and training of nonprofessional personnel at reference desks in selected college and university libraries," $193-200$

Thomassen, Cora E, ed., CATV and its implication for libraries, rev. of, 418-20

Thompson, Donald E., Indiana authors and their books, 19171966, rev. of 79

Thompson, Lawrence S., comp., The new Sabin, rev. of, 81-82

Thomson, Sarah Katharine, Interlibrary loan policies directory. rev, of 429

Timberlake, Mary E., retired, n310

Tiry, Marie Helene, Sister, O.P., deceased, n62

Tisdel, Kenneth S., retired, n62

Tolliver, Don L., and Westerberg and Baaske, "Overdue policies: a comparison of alternatives" (CぬRL 35:354-59), comments, 71-74; responses, $72-$ ments, 71-74; responses, $72-$

Tomko, Jean R., retired, n27071

"Topic A," Johnson, editorial, 95

Tsuneishi, Warren M.; Buckman, Thomas R.: and Suzuki, Yukihisa, eds.. Issues in library administration, rev. of, $230-31$

"Twenty-six CLR fellows will undertake varied projects in 1975-76 as members of Council's seventh class," n182-83

Tyler, Sara, retired, n339

\section{$\mathrm{U}$}

Umberger, Margaret, rev. ( $\mathrm{Li}$ brary research guide to religion and theology), 162

"Union or professional organization? A librarian's dilemma," Commerton, 129-35

Unionization: the viewpoint of $\mathrm{li}$ brarians, Guyton, rev. of, $428-$ 29

"Universal gift form and instructions," ACRL Rare Books and Manuscripts Section. Committee on Manuscripts Collections, n95-96

"University libraries as economic systems," Marchant, 449-57

"University libraries in Pakistan," Haider, 379-83 
"The use and training of nonprofessional personnel at reference desks in selected college and university libraries," Boyer and Theimer, 193-200

"Use of the reference service in a large academic library,' Balay and Andrew, 9-26; comment, 322-23; response, 323

"A user study of a computer retrieval system," Kiewitt, 458 63

Using the chemical literature: $a$ practical guide. Woodburn, rev. of, 243-44

"Using the 'Guidelines': a study of the state-supported two-year college libraries in Ohio." Clark and Hirschman, 364-70

\section{V}

Van Jackson, Wallace, prof. \& port., n61

Vesenyi, Paul E., An introduction to periodical bibliography, rev. of, $332-33$

"Videocassettes available," n319

Voigt, Melvin J., "Acquisition rates in university libraries" 263-71: ed., Advances in itbrarianship, v.5, rev, of, 521 23

\section{W}

Wahba, Susanne Patterson, "Job satisfaction of librarians: a comparison between men and women," 45-51

Walker, Gay, "Preservation efforts in larger U.S. academic libraries," $39-44$; comment, 322

Walker, John F., and Kohut, "Allocating the book budget: equity and economic efficiency," $403-10$

Walling, Ruth, and Farber, eds., The academic library: essays in honor of Guy R. Lyle, rev. of. 238

Walls, Esther J., prof. \& port., n23

Weatherford, John W., rev. (Unionization), 428-29

Weeding library collections, Slote, rev. of, 424-25

Weinerth, David, and Biblarz, Capron, Kennedy and Ross. "Professional associations and unions: future impact of today's decisions," 121-28

West, Carlton $P$., retired, n271

Westerberg, Judy, and Baaske and Tolliver. "Overdue policies: a comparison of alternatives" (C\&RL 35:354-59), comments, 71-74; responses, 72-74

Whalen, Jean, "Report on ACRL Preconference" n241-42, n262

White, Lucien $W$., deceased, n129

Wijasuriya, D. E. K. Lim, Huck Tee; and Nadarajah. Radha, The barefoot librarian: library developments in Southeast Asia with special reference to $\mathrm{Ma}$ laysia, rev, of, 516-17

Wilkinson, John; Plate, Kenneth and Lee, Robert, "A matrix approach to position classification," 351-63

Wilson, T, D., and Marsterson, W. A. I. Local library cooperation, rev. of, 42021

Wood, Alberta Auringer, rev. (Map librarianship), 422-23

Woodburn, Henry M., Using the chemical literature: a practical guide, rev, of, 243-44

ghide, rev, of, $243-44$
"Work attitudes and union membership," Simonds, 136-42

Wright, Christopher, "Inside Washington" n4: n40-41; n73-75;n108; n141; n180-81; n73-75; n108; n141; n180-81;
n217-18; n240, n260-61; n280: n320-21

Wu, Eugene, rev, (Asian and African collections in British (ibraries), 242-43

$$
\mathbf{X}, \mathbf{Y}, \mathbf{Z}
$$

Yagello, Virginia E., and Guthrie Gerry, "The effect of reduced loan periods on high use items," 411-14

Young, Kenneth E., port., n106

Zachert, Martha Jane K., Simulation teaching of library administration, rev, of, 421

Zipkowitz, Fay, rev. (Application of minicomputers to library and related problems), 517-19 